retard the earth's rotation, but this is exactly balanced by the cotnter-trades of the circumpolar vortexes, blowing from west to east.

I cannot agree with Mr. Clement Ley when he says that it involves a fallacy to explain the mean winds, or great currents, on one principle, and the actual winds, or temporary currents, on another. If the great currents were much feebler in proportion to the temporary currents than they are, the mean prevalence of east winds in the tropics, and of west winds in the higher latitudes, would be discernible only as a residual fact when a number of anemometric observations made at various places were completely discussed. JOSEPH JOHN MURPHY

\section{The Germ Theory}

YouR number for March 22 contains a review of my work on the Germ Theory of Disease, which, in some points, conveys so erroneous an impression of my exact position that I must ask you to allow me space for a few remarks regarding it.

Adverse criticism is what the author of such a book as mine expects, and, to some extent, desires.

A fair representation of his views and arguments, is what every author may insist on as a right.

It is the misleading manner in which my position is stated in your review that has induced me to pen this note.

To or e or two of your statements I would refer in illustration of what I complain.

$\Lambda$ fter referring to my expressed belief that contagia are living organised particles - an opinion held by many eminent physicians and men of science-your reviewer says: "If, however, the particles in sheep-pox, small-pox, and vaccine be the infecting matter, they are easily seen by the microscope, and ought, therefore, to be found in the blood, but such is not the case." This, the old and stock argument against the germ theory, is specially dealt with by me on two different occasions-at p. 25 , et seq., and at p. 204, et seq. If it was worth your reviewer's while to raise this old objection to the germ theory, it was equally worth his while to make some reference to my explanation of the fact on which it rests. This he has not done-a manifest unfairness

A little further on the review says : "Increased elimination of urea is explained thus: The increased consumption of liguor sangrainis by the contagizm particles leads to increased formation of retrogressive albunnen and of wrea. It seems by this that contagium particles have livers and kidneys."

The part which I put in italics is put in your review within inverted commas, conveying thereby the impression that it is a correct quotation from my book. It is far from being so. As given by you, it is a misquoted short passage, separated from its context, and altered to suit the purpose of your review.

The chapter on increased elimination of urea is perfectly clear and intelligible to any ordinary mind, and contains nothing which justifies your reviewer in attributing to me, as he has done, the absurd belief that contagia are possessed of livers and kidneys. Neither is he justified in using the words "eat" and "drink" to express the action of a minute organism on its enviromment. Such phraseology can serve only to mislead those who are ignorant of the mode in which these organisms grow; and is quite inapplicable to any nutritive process which goes on in such organisms as I have described contagia to be.

Your reviewer quotes my statement that "if we were to oleed, to purge, to give antimony to, or even simply to withhold food and water from all the cases of typhus and enteric fever which occur, there can be no doubt that we should find the mortality from these diseases greatly increased ;" and remarks on this, "Dr. Maclagan is right here, for by simply withtholding food and water there can be no doubt that he would greatly increase the mortality by starving his patients to death." Your reviewer seems to be unaware that $I$ refer in these remarks to a mode of treating fever which at one time did prevail.

To one other point I would refer in illustration of your reviewer's inaccuracy.

He says "the heat of specific fevers is partly ascribed to the propagation of the contagium causing increased consumption of tissue. But increase of living matter causes the disappearance of heat, not its production."

Even according to this, your reviewer's own somewhat awkward statement of the matter, the increased heat is attributed by me to increased consumption of tissue, indirectly brought about by the propagation of the contagium. Nowhere do I say that in. crease of living matter causes production of heat ; and nowhere does your reviewer attribute such a statement to me. Quite the contrary. I distinctly say that the increased production of heat results from increased disintegration of the tissues; and your reviewer distinctly attributes this saying to me. What, then, is the meaning of the latter part of the sentence just quoted? It bears but one interpretation. Your reviewer attaches to the first half of the quotation a meaning the reverse of that which it conveys. While saying that I ascribe the increased heat to increased consumption of tissue, he seems to think that he is saying something quite different, and pens his criticism accordingly. If he thus misunderstands his own statements, I need, perhaps, scarcely be surprised at his sometimes misinterpreting mine. I do object, however, to such misinterpretations and inaccuracies appearing in so influential a journal as NATURE. Dundee

T, MAClaGaN

SEXUALITY IN PLANTS 1

THE concluding part of the tenth volume of Pringsheim's Fahrbuicher contains three papers, one of them by Dr. Arnold Dodel, of Zurich, being of the highest importance. This paper occupies the greater part of the present Heft, and is illustrated by eight coloured plates. The title is "Ulothrix zonata, its Sexual. and Non-Sexual Reproduction, a Contribution to the Knowledge of the Lower Limit of Sexuality in Plants." The anatomy and life-history of the Ulothrix is exhaustively treated, the whole paper being a model of careful and accurate research, as well as a valuable contribution to our knowledge of the lower plants. The paper is divided into sections, of which the following is a short summary. The results given are those obtained during fourteen months' consecutive observation of the plant. The genus Ulothrix has been divided into many species, but Dodel shows that $U$. zonata is so variable in its different stages that most of the so-called species must be reduced to one. The alternation of generations is very remarkable and divisible into four stages. During the progress of the alternation of generation three distinct forms are to be distinguished, two being filamentous generations, and the third a zygospore generation. The filamentous generations are invariably produced non-sexually and reproduce themselves repeatedly, forming, in fact, the plant known to systematic botanists as Ulothrix zonata. The third generation, the zygospore, was unknown till discovered by Dodel. In the long series of filamentous generations two distinct forms are to be distinguished. The first is produced non-sexually and is the autumn or winter generation. It develops non-sexual macrozoospores and quickly spreads the species in a given locality. The second is a sexual stage developing microzoospores. It arises from the non-sexual macrozoospore, and gives rise to the microzoospores which by conjugation form the third generation, the zygospore or zoozygospore.

The production of the microzoospore-forming generation terminates the series of filamentous generations. This stage is found in spring and summer, and by giving rise to the zygospores which by remaining in a state of rest for some months during the hot dry summer weather, reproduce the plant in the autumn. During the hot weather the filamentous generations more or less completely disappear. The zygospore generation, although a product of gamogenesis, is itself non-sexual.

Ulothrix zonata exhibits polymorphism in a remarkable degree, hence many forms looked upon as distinct species must be suppressed. This opens up a wide question in regard to other algæ, and shows how essential it is to obtain an accurate knowledge of the life-history of all forms.

The cells of Ulothrix give rise to a variable number of zoospores. A mother cell may form $1,2,4,8,16$, or 32 zoospores, thele being no obvious distinctions between the sexual and non-sexual zoospores. On the one side is the large macrozoospore with four cilia, and then there is every gradation down to the smallest microzoospore

I Jahrbücher für wissenschaftliche Botanik. Herarisgegeben von Dr. N' Pringsheim. Zehnter Band, Viertes Heft. Leipzig: Engelmam, $x 876$. 